\title{
A Multi-Purpose Serials Record
}

Mr. Bennett, audio-visual aids librarian, West Virginia University, until last September, is now a student at the Graduate Library School, University of Chicago.

$\mathrm{L}^{\mathrm{m}}$ IBRARIANS will recall the difficulties involved and the hours consumed in I939-40, and again in 1943, when they were asked to report the serial holdings of their libraries for the Union List of Serials. Tens of thousands of man-hours were expended in checking the preliminary editions of this list and its Supplement against library catalogs in the attempt to make complete, accurate reports of holdings.

This was true, at all events, if West Virginia University Library's experience was typical. The flow of materials to be cataloged was blocked, except for "rush" items, and a backlog allowed to accumulate while catalogers pursued the double chore of going through tray after tray of the card catalog, and then transcribing the record of holdings from the shelflist.

The end-product was ample compensation for the tedium of those long hours, since few will argue that the U.L.S. is not worth the effort that was put into its compilation. Staff members at this library, realized however, that something should be done to provide a speedier, more efficient and wholly accurate method of checking such lists. They were well aware that both the catalog and shelflist contained inaccuracies. The answer, they agreed, probably lay in the setting up of a comprehensive serials record in which accuracy, once achieved, could be sustained.

Because of inadequate personnel, no staff member could be spared at the time to attack the problem. Late in 1945, however, the writer was assigned the task of devising a serials record which would meet the needs of the library. An inventory of the book collection. (the first in nearly twenty years) was under way, and it seemed a logical time for reorganization.

The writer began a study of the peculiar problems posed by the acquisition and processing of serials. Certain elements of chaos were immediately discernible; others were soon revealed. Many continuations and periodicals, for example, were inadequately or incorrectly cataloged. Many serials had been cataloged as separates, and had eluded the checkers of the U.L.S. Dash-statements of holdings in the main catalog had not been kept uniformly up-todate.

Many shelflist entries were inaccurate. In earlier. years, mass accessions of serial sets had been listed in blocks, and all too often the blocks contained fewer or more units than called for by the number of volumes represented. Dates indicating time spans covered by individual volumes were often omitted or inaccurately listed; e.g., reports covering fiscal years, and volumes covering only a portion of a year, were designated simply by calendar years.

Separate checking records for different types of serial publications were maintained, and the need for unification was apparent. In 1942 there had been set up in the reference department a kardex checking record for periodicals. Checking records for state documents and for certain serials received on exchange, were in need 
of reorganization. For many serial titles no checking records were maintained at all. The shelflist, in many instances, provided the only checking record for series. Order work had not been efficiently organized at that time, and much of the purchasing of monographs and other series was hit-ormiss. Very few standing orders had been placed with publishers of important serial titles.

Many volumes in the stacks were discovered to have been bound incomplete, and the shelflist, in most cases, carried no notes about missing issues. Little progress had been made in setting up definite policies about the binding of serials, and constructive action in this area was needed.

In an attempt to discover what approaches had been used in other libraries to solve serials problems, a number of letters were sent out, asking for information and advice about methods, equipment, and card forms. Responses indicated that some libraries had good checking records, but that none had established multi-purpose records containing more or less complete information about individual titles.

It was determined that, if at all possible, the library's record should be a complete record, in which any question about a serials title could be answered quickly. (e.g., What exactly are holdings? How do we acquire issues, and from whom? Are the volumes in the stacks complete volumes? How many issues of an annual report do we bind together?) It was realized that, of course, in many instances only the main catalog could be expected to carry full information.

After a careful exploration of deficiencies and present and future needs, the head cataloger and the writer determined what functions our serials record might reasonably be expected to perform, and what needs it could be shaped to meet adequate- ly. These discussions were influenced by the seeming desirability of establishing, within a very few years, a serials and binding department in which acquisition and processing activities would be combined with the servicing of all serials publications.

\section{Requirements}

A statement of the functions and needs agreed upon-all of which have been incorporated into a serviceable recordshould be accompanied by the qualification that, although a sizable portion of the record has now been in service for two years, a longer period is needed for testing whether or not all contemplated needs have been provided for. Only minor snags have appeared so far, and the flexibility of the record has made ready solutions possible.

I. Complete Record. First of all, the serials record was to be both checking record and shelflist record in alphabetical order. It was realized that a shelflist record arranged alphabetically by author and title was a new departure, and would not be universally sanctioned. However, its practical merits far outweighed those of a classified arrangement. The latter, it was felt, would be completely justified only at inventory times, the intervals between which at West Virginia University Library are so great as to present no serious objection to the alphabetical arrangement. It was believed that, for inventory purposes, the cards in a single tray could be removed, arranged in classified order, rearranged after checking against stack holdings and location file, and replaced within a day's time.

Furthermore, an alphabetical arrangement would greatly facilitate the task of reporting the library's holdings to the compilers of the U.L.S. The speed with which dealers' catalogs and exchange lists of serials could be checked against an alphabetical 
record was also a factor of particular importance, since great emphasis has necessarily been laid upon filling gaps in the library's serials sets.

To prevent duplications in assigning call numbers it was determined that referral cards bearing call number, author, and/or title, and stamped with the legend, "For Holdings See Serials Record," would be inserted in the shelflist.

2. Duplication of Effort to be Prevented. In earlier years, countless hours had routinely been spent in withdrawing cards from the catalog when new volumes were added, revising dash-statements of holdings, and refiling cards. This was felt to be a needless expenditure of staff time, despite the convenience afforded borrowers by carrying such information in the main catalog. It was decided that, as work on the serials record progressed, cards in the main catalog would also be stamped "For Holdings See Serials Record," and that holdings would no longer be indicated by pencilled dash-statements.

During the two years, no serious objections to this change in policy have been voiced. The patron is now instructed to fill out call slips on the assumption that the volume he wants is among the library's holdings. If the volume is not in the stacks or its book card not in the location file, reference to the serials record quickly produces a correct report for the borrower. Since the catalog formerly contained many errors in dash-statements of holdings, and circulation assistants had usually to check the shelflist to confirm or disprove pencilled notes in the catalog, the present procedure assures improved service.

3. Provision for Separately Cataloged Items. As in many libraries, a host of items published as parts of series have been cataloged separately in W.V.U. Library. Inclusion of separately cataloged serials in the record seemed fairly important, particularly if complete holdings were to be reported to U.L.S. Their inclusion would be useful also when time could eventually be found for recataloging them as series.

These three were essential considerations, and came first in planning, but there were a number of others which can be stated more briefly. It was agreed that the serials record should make provision for:

4. Essential notes covering irregularities in publishing history of many titles.

5. Appropriate cross references if entries used in W.V.U. Library vary from the U.L.S. entry.

6. System for claiming numbers or volumes not received-possibly by vari-colored metal signals attached to cards in a systematic manner.

7. Listing of second copies, particularly West Virginia items, of which two copies are regularly accessioned.

8. Recordings of items for which standing orders have been placed with the Library of Congress for analytics.

9. Listing binding specifications.

Io. Inclusion of closed entries.

I I. Collation record, when needed.

12. Noting sources of serials publications, and methods of acquisition.

With these requirements determined upon, it was possible to select equipment and devise card forms, and to establish routines for securing and transcribing accurate information about the library's serial holdings.

\section{Equipment and Card Forms}

The problem of selecting equipment was rather easily solved. From the beginning, it was felt that only a visible-index arrangement would be suitable, for the record must possess in high degree the essential virtues of compactness, flexibility, and simplicity.

Several types of visible-index equipment were inspected and the possible choices narrowed down to two well-known types 
of cabinets. After carefully weighing their respective merits, orders were placed for three Acme duplex cabinets, of the hingeand-hanger type. Each of these contained thirteen I88-card trays, with a cabinet capacity of $24444^{\prime \prime} \times 6^{\prime \prime}$ cards. Since an estimated 5200 serials titles are represented in the W.V.U. collection, this number of cabinets would allow for an expansion of a little over 2000 titles.

It is possible in this type of cabinet to use both sides of a card for record-keeping (approximately 48 square inches), and, when needed, to employ 4-page folded cards with almost double the writing space available on single cards. It is also possible to use auxiliary rider sheets providing additional recording space, which can be hung over the master cards, and replaced or supplemented by others as the need arises. Judicious utilization of these features has resulted in far greater flexibility in the record than was anticipated in the early planning stages.

The challenges faced in devising card forms for the serials record were many. The allotment of space for shelflisting purposes was of primary importance, of course. but first there had to be determined the amount of space needed for carrying other essential information, such as author and title, call number, source and method of acquisition, and binding instructions.

Many experimental forms were drawn and discarded in favor of improved ones. By a gradual refining process, two basic master forms (and 4-page versions of each) were devised.

The first of these was designed for the type of serial which requires only the simplest of notations; e.g., Harvard Economic Studies.

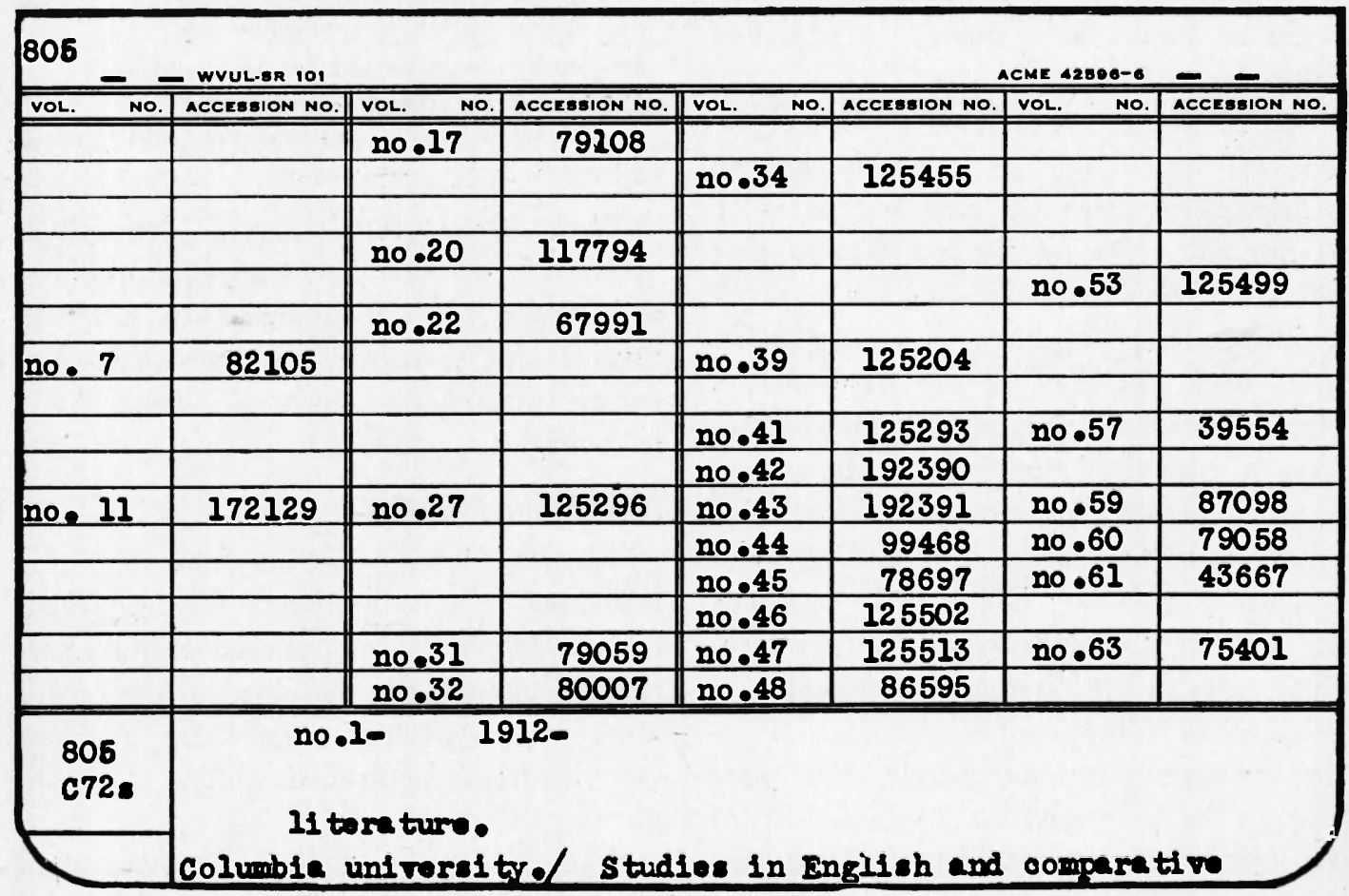

Figure i. Front of Basic Card Described in Text 


$$
\begin{array}{rr}
\text { Vol. } & \text { Acc. No. } \\
\text { I } 8 & 123456 \\
19 & 134567 \\
20 & 145678
\end{array}
$$

The second was devised for serials which require, in addition to volume and accession number, a designation of dates spanned by single volumes. In the case of periodicals issued weekly, for example, volumes of which often cover odd portions of calendar years, a fairly long entry is needed; e.g., Saturday Review of Literature.

$$
\begin{array}{lcr}
\text { Vol. } & \text { Date } & \text { Acc. } N o . \\
\text { v. 18 } & \text { Ap. 30-O.22. 1938 } & \text { 176430 } \\
\text { v. 19. } & \text { O. 29. 1938-Ap.22 '39 } & \text { 1 } 87697
\end{array}
$$

The same adaptable form can also be used, for example, in transcribing the shelflist record for acts of a state legislature, which requires even lengthier notations; e.g.,
West Virginia. Legislature./ Acts of the Legislature.

Year

Session

Acc. No.

I 933 Ja. I I-Mr. 13, 4 Ist \& Ext Sess; 12969 I Ap. 10-Je.3, Ext Sess

The two basic forms are identical in most respects, so that reference to them for information other than shelflisting is uniform. On the first of these forms, shown in Figures I-2, space is blocked off for 109 entries. The 4-page version, identical except for a folded upper section accommodates 120 additional entries.

The second basic form differs from the first in one respect only. No columnheadings or vertical columnar lines are printed in the shelflisting areas on either the front or verso of the card. Depending upon the nature of listing required by individual titles, the shelflisting space can

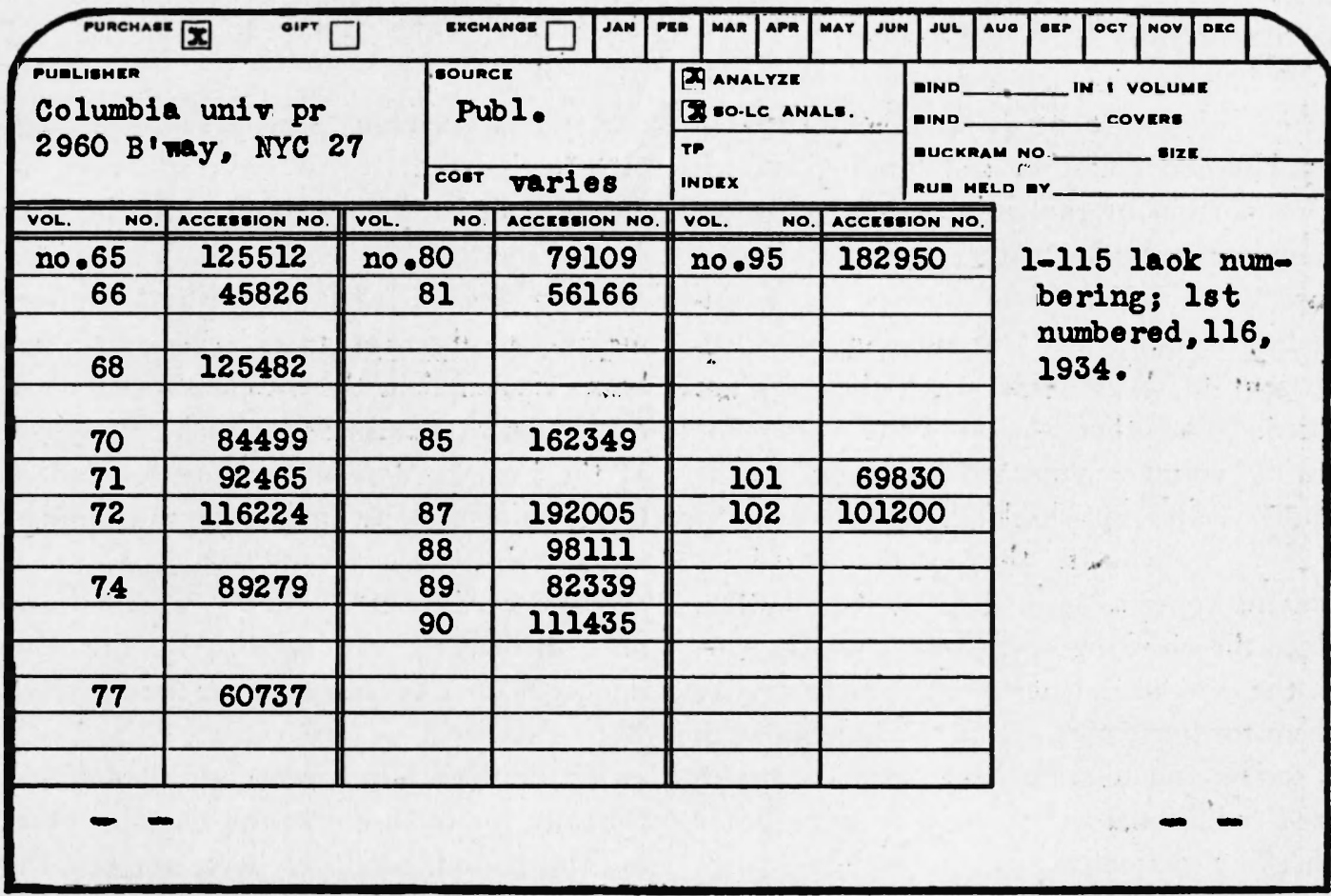

Figure 2. Verso of Basic Card Described in Text 
be divided into two, three, or four columns, providing for the listing of from 62 to 109 volumes. On the 4-page version of this second form, from 122 to 229 volumes can be listed.

Three auxiliary riders are used for recording currently received, unaccessioned issues. The first is divided into three columns, with spaces numbered I to 50 ; the second is numbered $5 \mathrm{I}$ to $\mathrm{O}$. These riders are used for checking numbered series, annual publications checked by calendar year, reports covering fiscal years, and publications bearing volume number and date.

The third rider was devised for checking issues of certain university studies and other series issued in parts, and following no prescribed pattern of issue. It is used also for checking practically all monograph series which are analyzed in the main catalog. This form provides for checking volume or part number, date of receipt, cost, ordering of L.C. cards, and actual insertion of analytics in the catalog.

A fourth rider, devised largely in anticipation of future needs, can be used as a combination collation and binding record. One portion of the sheet is for listing incomplete volumes, either volumes bound incomplete and held in the stacks, or unbound volumes held for missing issues, to be sent to the bindery when the gaps are filled. The other portion of the rider is for listing volumes prepared and sent to the bindery, and for checking their return.

For periodicals, the serials record at present contains only shelflist information, since the checking of current issues is done in the reference department, which services them for borrowers. If, as is contemplated, a serials and binding department is organized, additional riders will be devised for checking periodicals at the serials record.

Long before the work of devising card forms had been completed, routines for making a complete file of serials represented in the library's collection were set up, and the work of securing complete, accurate information was begun. A work card was made for each title that had been reported to U.L.S. Entries were verified and notes made about cross references required because of variations between the U.L.S. entry and the one established in the W.V.U. Library's catalog (usually an L.C. entry). Call numbers were verified for each title, and placed on the work card.

Then began the search for all titles which had not been reported to the U.L.S. The kardex checking record for periodicals was combed for omitted titles, including all of those which had either not been bound and cataloged in 1939, or which had begun publication since that time. The checking record for state documents was carefully searched, and work cards made for titles which were to be included in the serials record. The gift and exchange checking records yielded many unreported titles also.

After this combing process had been completed, the work cards were arranged in classified order for a card-by-card checking of the shelflist. This was done to check the accuracy of entries and shelflist information, to discover titles which had not been uncovered in the compilation of work cards, and to determine for each title which of the basic card forms was to be used in transcribing shelflist information in the serials record.

This card-by-card check revealed not only incorrectly cataloged titles but also hundreds of items belonging to series which were cataloged as separates. Slips were made for these latter items and filed alphabetically for inclusion in the record. During this period, catalogers were revising the filing in the main catalog and turned up many separately cataloged volumes. Slips 
for these items were also filed and later incorporated into the record.

After the printed card forms were received, and as sections of the shelflist were completely checked, the work of transcribing holdings and other information was gotten under way. Referral cards for serials in the IOO's and 200's were placed in the main shelflist, and shelflist cards withdrawn. As the preparation of serials record cards for these sections was completed, the cards were proofread, revised, and filed in classified order, with work cards clipped to them. Cross references were typed on unprinted light green cards, and filed with the titles to which reference was made.

At first this work was done by the writer. Later the clerical staff was increased, and corrected shelflist cards were given to a typist for transcribing.

When checking of the shelflist had been completed (with two exceptions: the 500's and 6oo's), and serials record cards made, the cards were alphabetized and installed in the cabinets. As cards were made for the other sections of the collection, they were interpolated in their proper alphabetical stations.

Although it is possible to remove cards from their hangers, and to insert them into a typewriter for adding new volumes, it has been thought unwise to subject the cards to any harder use than necessary. When new volumes are added now, the entries are made in black India ink.

For purposes of keeping accurate statistics, each addition is checked lightly in pencil, and a small metal signal attached to the edge of the card. At regular intervals, these additions are counted for the monthly statistical record, and signals removed.

A longer period should doubtless be allowed for testing fully the efficacy of the serials record which has been put into service in the West Virginia University Library. However, it is not too early to make a few generalizations about its use.

Whether or not such a comprehensive record would prove entirely workable in a large university or public library is perhaps open to question. Its compactness might conceivably be a disadvantage if too large a number of staff members had to make constant reference to it.

From the cataloger's point of view, the record makes for great simplification in adding serials. Additions can be made directly in the record, and as soon as volumes are labeled, they can be sent on to the stacks, usually without any necessity for withdrawing and revising cards in the main catalog.

The order section has found the checking of exchange lists and dealers catalogs expedited by an alphabetical record in which gaps in the library's holdings are easily discernible. The circulation department's use of the record is similarly facilitated by the ease with which the completeness or incompleteness of holdings can be scanned.

Under the conditions which formerly prevailed, staff members often had to search in as many as three or four places for information about a serials title. Checking records, formerly scattered, have now been consolidated, and combined with the shelflist record. It has proved greatly advantageous to have a complete record, easily accessible to catalogers, assistants in the order section, reference librarians, and circulation assistants.

The foundation stone for a needed phase of reorganization of the library has been fashioned and made serviceable. Duplication of effort has been eliminated, and the possibility of complete accuracy in a single record of serials assured. 